\title{
Sidoarjo Film Festival 2019 as an Effort to Generate the Indonesian Film Industry
}

\author{
Siska Armawati Sufa ${ }^{1}$, Rusli Kustaman ${ }^{2}$, Henri Subiakto ${ }^{3}$, Ipit Zulfan ${ }^{4}$, \\ Teguh Dwi Putranto 5 \\ 1,2,4Communication Faculty, Padjajaran University, Bandung, Indonesia \\ ${ }^{3,5}$ Social and Political Science Faculty, Airlangga University, Surabaya, Indonesia \\ Coresponding Author's Email: siska19003@mail.unpad.ac.id
}

\begin{abstract}
At present, various national film titles have begun to dominate in all regions of Indonesia. Beginning around 2018, the number of film viewers in the country reached 50 million people, an extraordinary achievement, with only 42 million in the previous year. Increasing the number of film viewers in Indonesia certainly can not be separated from the hard work of creative producers in the field of film that continues to produce real work with a variety of interesting, creative content, and of course, contains elements of humanism and culture of the homeland that are still in great demand today. Indonesia, which has a rich cultural and regional potential, has a great opportunity to continue to develop the film industry by raising a variety of content that is culturally charged, and historical value with a little added element of romance in the storyline. However, at the time of the growing popularity of national films, the domestic film industry in several regions in Indonesia still faces many very complex problems, including the Sidoarjo Regency in East Java. Various attempts were made by the government of the Sidoarjo Regency to revive the film industry in its area, one of which was the holding of the 2019 Sidoarjo Film Festival (SFF) in collaboration with Sidoarjo Creative (Sirive). This study aims to determine the efforts of the Sidoarjo Regency Government in reviving the film industry through SSF 2019 as one of the new business opportunities for young creators in the Sidoarjo region, through a qualitative approach with interview methods to the Government Public Relations of Sidoarjo and Sirive (key informant) as the organizer of SFF 2019, and young Sidoarjo creators (informants) as SFF 2019 participants. The results of the study found that SFF 2019 was much sought after by young creators in honing and developing talent in producing indie or short movies so that they were expected to be able to become new business opportunities in creative content in the Sidoarjo regency through activities similar in a variety of event formats, in the form of focus group discussion, workshops, seminars, film festivals, and screening day.
\end{abstract}

Keywords: film industries, Sidoarjo, film festival, Sidoarjo Creative

\section{INTRODUCTION}

Slowly, the film can become a weapon that is quite 'deadly' that can be exploited by an intelligent and evil nation as a medium to damage the character of other nations. The film can be one of the media that is now widely referred to as proxy war because the damage is massive. The film can also be a tool of political 
propaganda for political elites to win power, break down national unity and displace the ideological paradigm of a country.

The film is an important part of human life, maybe even not only important for mere individual entertainment. The film industry can be a potential land in advancing our nation both in terms of economy, science, and even become one of the mediums to preserve Indonesian culture (Julian, 2017).

Indonesia's film industry market is quite promising. This is consistent with its amazing growth, both in terms of the number of viewers, the big screen, and the many Indonesian movies that millions of viewers watched.

There was a very rapid increase in the number of film viewers in Indonesian cinema. "In the last five years, it has hit $230 \%$. The number of monitors in the studio has also increased rapidly over the past three years from 800 widescreens (screens) to 1,800 . Indeed, Indonesia is known as the market for the 16th largest box office films in the world with a market value of $\$ 345$ million or about $\$ 4.8$ trillion. Nevertheless, the number of screens is still very small, Since 10,000 screens should be suitable for Indonesia with a population of 260 million people (Susanto, 2019).

And millions of viewers have watched the many films entering the box office in Indonesia. Because Indonesia can be said to be a large market for the film industry, it is no longer difficult for Indonesian films to reach the standard target of an audience of four million viewers.

Indonesia's largest population in Southeast Asia, the rapid growth of the film industry is also motivated by government policies that give foreign investors the freedom to fully fund Indonesian film production as a contributing factor to the ease with which many people enjoy films. However, more and more Indonesian films are made, the quality of which is not inferior to foreign films, and again, the human resources limitations of the Indonesian film industry.

As we know, the current Indonesian government is entering a new period with a change of leadership and certainly, there will be a new policy that is expected to provide innovation for the sustainability of development in the future. Based on the National Medium-Term Development Plan (RPJMN) 2015 - 2019, Nawacita is nine development priorities for five year period as the vision of the administration of President Joko, Widodo and his deputy, Jusuf Kalla. At that time, through Nawacita, Indonesia was hoped able to change and become a politically sovereign, independent country in the economic field and a personality in culture (Kominfo, 2015). One of the efforts to increase independence in the economic field is to encourage the growth of the creative industry, especially through the development of the cultural industry in the field of art and film industry.

The creative sector is one of the industries with quite rapid development compared to other industries. This is also evident from the creative industry's contribution to gross domestic product (GDP), which has continued to rise over the past three years.

The creative industry contributed IDR 852 trillion in 2015. This figure then increased in 2016 to IDR 923 trillion. Meanwhile, in 2017, its contribution will 
increase to IDR 990 trillion and last year it is estimated to reach IDR 1,000 trillion (Kompas.com, 2019).

Moreover, the government is currently pushing the ecosystem for the creative industries. Therefore, the government continues to improve and reduce regulations that have the potential to hamper the development of the creative industry as well as the digital economy. Creative industries deserve to be a consideration for millennials to open businesses and choose careers. For those who have or intend to move in the creative industry.

The increasing development of film entertainment enthusiasts in Indonesia has not been matched by an increase in the role of local governments in supporting culture, especially film, which is considered to be very minimal. Facilities or space to appreciate film works as one of the works of art is still very few that reach out in several regions in Indonesia. Some areas in the eastern part of Indonesia, which have less cultural facilities. Especially the government in regencies or cities have no initiative to motivate and support the development of film art in their region so that the current generation is also reluctant to enter to engage in the world or film work. To move the role of Indonesia's film industry, government and creative industries also need to intervene to create works of art that can be an inspiration to the wider community to be able to create business opportunities and new job reports (Sulistyoningrum, 2015).

Indonesian films are still considered to be lacking in human resources (HR) who are graduates of film school, although it has developed rapidly at the moment. Since the changing era, Indonesian films have developed rapidly. But as long as there is no supporting infrastructure and human resources, the Indonesian film industry will not be as strong as the Hollywood film industry.

The quality of human resources needed is human character and creative. A total of 14 sub-sectors of the creative economy that are of concern to the Indonesian government include computer \& software services, interactive games, video film \& photography, crafts, music, design (industrial design, interiors, visual communication, etc.), advertising, performing arts, broadcasting (television \& radio), architecture, research \& development, fashion, art \& antique markets, and publishing \& printing (LPPM UK Petra, 2015).

Sidoarjo as one of the districts in the East Java region and directly adjacent to Surabaya as the second major city in Indonesia is declared as one of the MSME Cities and is a strategic area for regional economic development to become an investment area. So that this year, the Sidoarjo regency government is collaborating with Sidoarjo Creative (Sirive) to hold the Sidoarjo Film Festival (SFF) event, which is a competition and film festival intended for Film Community and young citizen throughout the Sidoarjo regency.

Based on the background, this study would like to explain about the efforts of the Sidoarjo regency government in arousing the interest of the people of Sidoarjo community in the field of the creative film industry. 


\section{LITERATURE RESEARCH Creative Industry}

The word creative industries are borrowed from developed countries and the 'original' definition in Indonesia is often interpreted differently in that it is not always considered to apply exclusively to the promotion of individual innovation and intellectual property. Instead, long-established traditional cultural industries are seen as creative industries, despite their strong commitment to heritage values and loyw attention to innovation and the creation of knowledge, which are the main features of creative industries (Fahmi, 2015).

The term creative industry is another term for the culture industry. The term was first used in the early 1990s in Australia but was rapidly developed by the British government in the late 1990s. The British Government specifically formed Units and a Person in charge of Creative Industries under the Ministry of Culture, Media and Sports (Primorac, 2006).

Indonesia has realized that in the ASEAN and global economies, the creative economy and its parts, namely the creative industry, can be hoped to grow, compete and gain excellence. Since the creative economy can be a cornerstone for Indonesia's economic development, where it needs the synergy help of all Indonesians to make a "leap" with an emphasis on goods and services development coupled with knowledge, talent and innovation, and intellectual property. Scholars' partnerships, business people and government are the foundation of the creative economy's development to operate harmoniously and overlap (Purnomo, 2016).

According to the United Nations Conference on Trade and Development (UNCTAD), the creative industries are (UNCTAD, 2008): 1) the cycle of creation, production, and distribution of goods and services using creative and intellectual capital as its main input; 2) part of a series of knowledge-based activities, focusing on art, which has the potential to generate income from trade and intellectual property rights; 3 ) consists of products that can be touched and intellectuals that cannot be touched or artistic services with creative content, economic value, and market objectives; 4) cross-sectoral nature between arts, services and industry; and 5) part of a new dynamic sector in the world of trade.

Indonesia has great economic potential in both consumer and product terms. We should not only be a goal for the other country with a population of 230 million people but also as a manufacturer. By leveraging all capital, including people, Indonesia still can stimulate economic growth. We don't want people to lead to the demographics of the disaster. Then, the large population has to become a massive force for economic growth. Making them as entrepreneurs is one effort that can be maximized to make that large population a positive value (Bisnis Indonesia, 2011).

Throughout Indonesia, where economic development, especially in the field of creative industries, most are located in Java and Bali. This is in line with hypotheses and empirical evidence from developed countries that creative 
industries tend to be concentrated in more developed urban areas and local economies (Lazzeretti et al., 2013).

It would also seem pointless to follow the current national strategy, which allows all local governments in Indonesia to promote creative industries in their localities. Because strategies promoting the development of creative industries are not applicable in all regions. In the more developed regions with enough human capital and diverse economic activities, such as some major cities on Java, it is sensible to encourage creative industries. However, attention should be paid to other economic sectors that also contribute to regional economies. Considering the much higher numbers and high growth rates of traditional cultural industries, it is obvious that these are also significant, although they will have different effects on the local economy. For areas where traditional cultural industries are highly concentrated, Policies aimed at encouraging these sectors could be more successful than those promoting the formation of new creative industries (Fahmi, 2016).

\section{Film Industry}

Cinema industry is one of a country's strategic locomotive industries with the power to transform it into economic value. The creative industries' economic analysis of the film industry will help to shed light on the industry and provide a map. Innovative creative industries are studied as part of the film industry's strategic management. The importance of the industry of cinema and TV series (film and serial film) With the growth of media and technological infrastructure, its economic role has increased (İncekara, 2013).

\section{METHODOLOGY}

This research is a study that uses a qualitative approach with the interview method. Qualitative research focuses primarily on the use of tools to analyze and understand the meaning in which certain individuals or groups are perceived to have resulted from a social or human problem (Creswell, 2010).

The interview is a method of gathering research data independently and systematically by one-way questions and answers and providing a framework for research goals (Susanto, 2019).

In this study, researchers will explore information through interviews with the Sidoarjo Film Festival 2019 committee to find out what the implementation of the 2019 Sidoarjo Film Festival to the creative industries in Sidoarjo. 


\section{RESULTS AND DISCUSSION \\ Creative Industry in Sidoarjo Regency}

Sidoarjo is a location that is always synonymous with various MSMEs or various factory industrial buildings that stand firm in several areas of Sidoarjo regency. Fishery products by fishermen from the sea or fish ponds, to agricultural, and plantation products are also there so that the creative industries have the opportunity to compete at the national and international levels.

Sidoarjo Regency Government has collaborated with various parties or stakeholders involved in developing creative industries in the region, ranging from the Department of Industry and Trade, the Office of Cooperatives and MSMEs, and private institutions from banks, entrepreneurship training institutions, nongovernmental organizations, mass media, and educational institutions starting at school level middle to college. The attention of the Sidoarjo government is not only in efforts to increase the creative industries in the fields of products and services, but also works of art, culture, and fashion.

The field of processed products produced by the people of Sidoarjo is very diverse, especially food and beverage products. More specifically, Sidoarjo Food and Beverage industry producers have long been incorporated in the Sidoarjo Food and Beverage Association abbreviated as ASMAMINDA and have been inaugurated with a notarial deed since 20 February 2017 located in Bluru Kidul, Sidoarjo Regency. Sidoarjo Regency as an area with waters that dominates the Sidoarjo region is widely used by the managers of ponds and also fishermen with abundant fisheries and sea catch, some of the ponds produced mostly are milkfish, while the catches from the sea are Shrimp, Kupang, and others. The community has begun to process the results of the fishponds and sea catches into various food products, some of which are: all variant of Bandeng Fish (crispy fried, smoke-milk, presto-milk), Kupang Crispy, and Shrimp Petis.

One of the creative industries in the fashion sector is Batik Jetis Sidoarjo, which has existed since 1675, located behind Jalan Gajahmada, Sidoarjo, increasing the rise of MSME centers in the Sidoarjo Regency. The Jetis village area developed rapidly after the founding of the Sidoarjo Batik Association (PBS) on April 16, 2008 by the local community with the aim of helping to market and maintain the stability of the selling prices of Batik Jetis, because indeed before the establishment of the association batik artisans had difficulty in marketing their products. Currently, Kampoeng Batik Jetis Sidoarjo has begun to improve its business strategy, the Government of Sidoarjo Regency in collaboration with stakeholders, especially from higher education institutions, plans to make Kampoeng Batik Jetis Sidoarjo an area of batik education-tourism.

The creative economic system is believed to shift the economic system that has been running as the agricultural economic system, industrial economy, and communication economy. Indonesia which is rich in culture and has a large population has enormous potential in developing this creative economy, including the development of creative industries in the fashion sector. With the 
democratization of the field of fashion, fashion today has metamorphosed from the primary needs of humans as the cover of bodies to the needs of fashion, style, and trends of humans (Jerussalem, 2009).

While in the field of art and culture, the Sidoarjo regency government has often held cultural performances in the Sidoarjo Alun-Alun Hall and also the Mpu Tantular Museum as one of the museums with the most complete collection in East Java, located in Sidoarjo regency. Meanwhile, the film art industry is still very little developed in the Sidoarjo regency. Meanwhile, the film art industry is still very little developed in the district of Sidoarjo. Since the 2000s, from 2 mall areas in Sidoarjo there has only been one cinema building. However, a few years later around 2015 a new cinema building began to emerge in Sidoarjo, in total there are 4 malls now and all are equipped with cinemas. Even in January 2018, the Sidoarjo Regent inaugurated the Community Literature and Children Literature Cinema Building within the Sidoarjo Regency Library and Archives Office.

After the provision of facilities and infrastructure in the arts and culture is complete, the Government of Sidoarjo Regency in the next steps is to increase the interest and talents of the young generation of Sidoarjo in the film industry. The effort was realized by the Sidoarjo Regency government in collaboration with Sidoarjo Creative (Sirive) as an institution consisting of several experts in the creative industry to hold an event titled Sidoarjo Film Festival (SFF) 2019 intended for young people who are members of the Film Community from all area of Sidoarjo regency.

\section{Sidoarjo Film Festival (SFF) 2019}

In the Republic of Indonesia Presidential Regulation Number 72 the year 2015, the creative economy industry is classified into 16 subsectors, while the film industry is included in the fifth subsector namely the Film, Animation, and Video sectors. To implement this subsector, the Sidoarjo Regency Government in addition to facilitating various facilities and infrastructure needs, also took the initiative to revive the film industry in its area.

SFF 2019 series of activities is a medium or a place to exchange ideas, share knowledge, and experience about the film industry organized by the Sidoarjo Regency Government in collaboration with Sidoarjo Creative (Sirive) intended for the Sidoarjo Film Community. This activity will be an activity that will be held annually. Sidoarjo Film Festival (SFF) 2019 has a theme about "Exploration and Village Potential in the Sidoarjo regency", with the hope that young filmmakers or Film Community in Sidoarjo who take part in the film festival will produce film works by displaying all the potential areas of Sidoarjo regency.

The aims of the 2019 Sidoarjo Film Festival (SSF) besides wanting to revive the creative industry in the film field is also to motivate the Film Community among young people, to better recognize, explore, and be proud to introduce the potential of Sidoarjo regency. Some of the activities of the Sidoarjo Film Festival (SFF) 2019 are as follows: 


\section{1) Movie Talk}

Movie Talk is a discussion activity with professional filmmakers from Sidoarjo who are members of the Sidoarjo Creative (Sirive) as a speakers with the name of the activity being "RASAN-RASAN FILM" (East Javanese language) in the Indonesian language meaning to talk about films. The speakers consists of creators, directors, producers, screenwriters and even make-up artists and crew wardrobe.
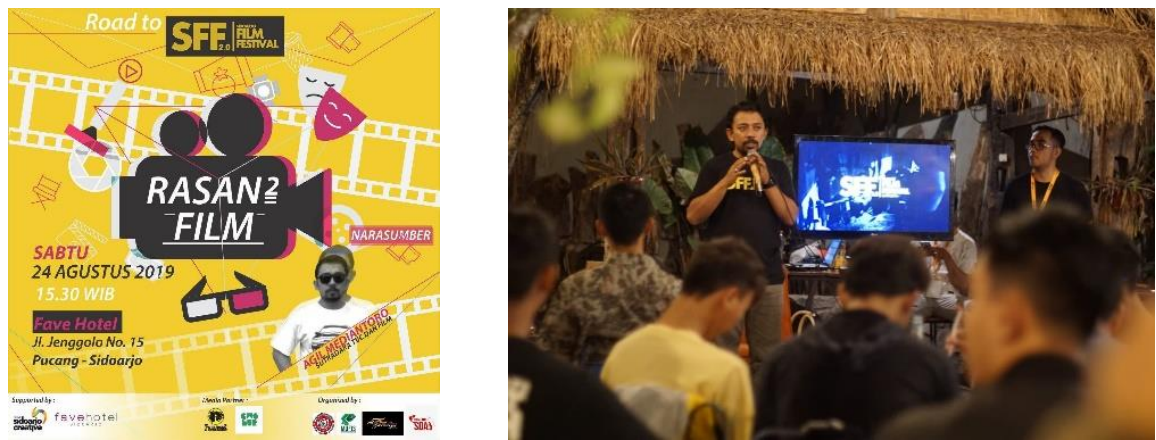

Figure 1. The Movie Talk Activity of SFF 2019

This discussion activity is intended for Film Community and young citizen of Sidoarjo to get closer and more clear to know, study, and develop their interests and talents in the film industry. The participants in the discussion consisting can explore, and ask the filmmakers as speakers in the discussion activities.

In the film industry, there are several stages, the production stage can be defined as the overall activity required to produce one copy (one print) of film. While the distribution of the essence is the whole function of distributor interaction with customers (customers) and the audience. The exhibition refers to the performance activities through the cinema network or individual sites (Eliashberg et al, 2006). This subject was also given in the discussion activity when held on August 24, 2019. Throughout this activity, the Sidoarjo regency government hopes that Sidoarjo millennial people are more motivated in developing an interest in the film industry. Furthermore, they can get to know more about the job descriptions, roles, and function of the film production team, so they understand that the film industry is one of the proud and promising professions from an economic standpoint. By knowing the division of teamwork in the film industry, millennial citizen of Sidoarjo can produce film works that are not only interesting in terms of screenplay scripts but also have elements of regional cultural values. 


\section{2) $10^{\text {th }}$ Nominations Screening}

The film festival, which has been socialized since the end of 2018, was attended by around 80 titles from participants from high school and vocational high school students in the Sidoarjo regency. This proves that the attention of the indie film community in the Sidoarjo region is quite high in demand. According to Syamsul Barry (2016), the interesting thing from the phenomenon of the growing community of this film is that not only is the number of film communities growing but because community films have a variety of forms, many explore local culture (stories, speech patterns, languages/dialects, arts, and culture) as well as having achievements worthy of being proud of, their achievements at national and international levels.

Out of the 80 films that were entered, 10 nominations for the best films will be screened on the Platinum Suncity Mall Sidoarjo cinema screen on October 03, 2019. Following are the 10 best short film nomination titles at the 2019 SSF event: 1) D'Dining Big, 2) Rumah Kosong, 3) Fix Taporop, 4) Mitos Siulan Malam, 5) My Great Grandfather, 6) Pluviophile Ardian Zislamin, 7) Rumah Batik Jawa Timur, 7) Dia, 8) Siapa Kita, Indonesia!, and 10) The X.

\section{3) Award Day}

In the end of October 2019, the Sidoarjo regency government announced the best film winner was won by the Film Community from the 10 November Institute of Technology Surabaya namely Kips Production, which consisted of students from citizen of Sidoarjo with the title of the short film is "My Great Grandfather". The film tells about efforts to maintain cleanliness and keep the environment away from waste. The film, which is packaged in a simple 10-minute scenario with the flashback plot, is considered by the SFF 2019 jury to meet all elements of the assessment, ranging from elements of story scripts, photography and shooting, the role of each talent, directing, to video editing.

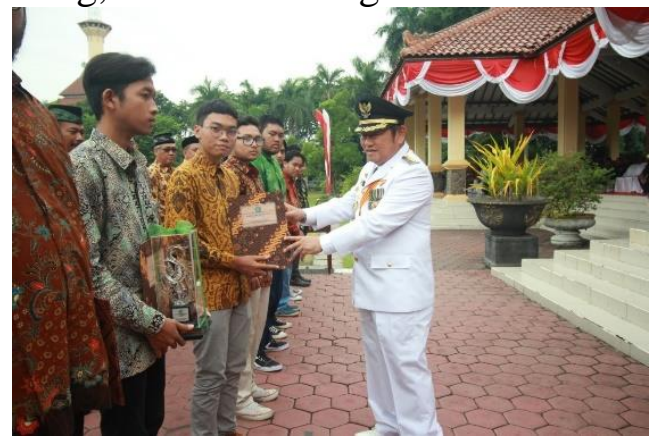

Figure 2. The Awarding Day by the Regent of Sidoarjo, Saiful Ilah

The Regent of Sidoarjo, Saiful Ilah, conveyed in his speech that he hoped that the existence of a film festival like this could become a medium 
in the potential of the Sidoarjo regency, and could be a forum for the young generation of Sidoarjo in developing their interests and talents in the film industry.

he overall aim of the 2019 Sidoarjo Film Festival event can be seen from several aspects as follows: 1) Knowing the level of interest of the citizen of Sidoarjo who are talented and interested in the film industry, 2) Growing the concern of various parties in supporting, developing, creating, and producing films that have value high cultural arts in accordance with Indonesian nationality values but also worth watching for the public so that they not only boast but also produce economic value for their creators, 3) Become the main space or place for the citizen of Sidoarjo to channel their interests, talents, and creativity to support the advancement of the Indonesian film industry comprehensive, especially in Sidoarjo Regency, 4) Identifying and developing young filmmakers in Sidoarjo.

In the current era of regional autonomy, the regional development agenda should be a synergy between the vision of national development and regional needs, which is formulated in a realistic vision of regional development. Second, the weakness of regional intelligence in identifying, exploring potential, and constructing regional needs (Darmawan, 2010). These two things become a reference for the Sidoarjo regency government in developing their regional potential by moving their citizen to explore the potential of the Sidoarjo regency to be of high value, not only in terms of art and culture but also politic, economic, and social.

The film is something inspiring, as expected by the Sidoarjo Creative Team (Sirive) through the Sidoarjo Film Festival 2019, to develop the film industry in the regions as well as to advance the Creative Economy Sector. Producing film can strengthen many sectors, including culinary, fashion, art, and cultural sectors so that the potential can be better known by the wider community. This is in line with the vision and mission of the Indonesian state listed in NAWACITA as nine development priorities not only in the economic field but also concerning development priorities in other fields, such as culture, education and defense and security.

\section{CONCLUSION}

With the holding of the 2019 Sidoarjo Film Festival, it is able to generate new business innovations in the film industry and make a business opportunity in the creative film industry. So that the growth of the creative industry in Sidoarjo increased and impacted on new businesses, especially young creators in SIdoarjo to be more productive in the creative industries, especially in the film industry. 


\section{ACKNOWLEDGMENT}

A project of this magnitude requires a network of support, thank you so much for my research team, especially for professor Henri Subiakto as my advisor in this research. I am particularly grateful to The Sidoarjo Regency Government, East Java, Indonesia. Thank you so much to Sidoarjo Creative (Sirive) team for making the study possible, and special thanks to Agil Mediantoro from Sirive team, as a key informant in this research. I will continue to develop research on creative economy, especially about the film industry.

\section{BIODATA}

Siska Armawati Sufa, S.Sos., M.I.Kom., is a lecturer of communication science faculty on Dr. Soetomo University, Surabaya, East Java, Indonesia, and a student of doctoral program on communication faculty, Padjajaran University, Bandung, West Java, Indonesia. She has a research interest in government public relations, government economic responsibility, marketing, health communication, business communication and film studies.

Rusli Kustaman, M.Sn., is a lecturer of Music \& Sound Designer on ISBI Bandung, Jawa Barat, Indonesia. He has a research interest in music, and film industries.

Prof. Dr. Drs. Henri Subiakto, SH., MA., is a professor of social and political science faculty majoring in communication science on Airlangga University, Surabaya, East Java, Indonesia.

Ipit Zulfan, S.Sos., M.I.Kom., is a student of doctoral program majoring in Communication Sciences, and a head of audio-visual laboratory on Faculty of Communication Science, Universitas Padjadjaran, Bandung, West Java, Indonesia. Teguh Dwi Putranto, S.Pd., M.Med.Kom., is a student of doctoral program on social and political science faculty majoring in communication science, Airlangga University, Surabaya, East Java, Indonesia.

\section{REFERENCES}

Creswell, J. (2010). Qualitative Inquiry and Research Design: Choosing among Five Approaches, 2.

Bisnis Indonesia. (2011). Kewirausahaan Industri Kreatif. PT Jurnalindo Aksara Grafika: Jakarta.

Darmawan, Cecep. (2010). Desa Peradaban. https://nasional.kompas.com/read/2010/09/13/16114269/twitter.com?page= all. Accessed on: November 06, 2019.

Eliashberg, J., A. Elberse, dan M.A.M.M Leenders. (2006). The motion picture industry: Critical issues in practice current research, and new research direction. Marketing Science 25 (6): 638-661. 
Fahmi, F. Z., McCann, P., \& Koster, S. (2015). Creative economy policy in developing countries: The case of Indonesia. Urban Studies. http://dx.doi.org/10.1177/ 0042098015620529.

Fahmi, F. Z., Koster, S., \& van Dijk, J. (2016). The location of creative industries in a developing country: The case of Indonesia. Cities, 59, 66-79. doi:10.1016/j.cities.2016.06.005

İncekara, A., Şener, S., \& Hobikoğlu, E. H. (2013). Economic Evaluation of the Film Industry in Terms of Strategic Management within the Scope of the Creative Innovative Industries: The Case of Turkey. Procedia - Social and Behavioral Sciences, 99, 636-647. doi:10.1016/j.sbspro.2013.10.534

Julian, Natashya. (2017). Industri Film Indonesia, Potensi Berharga yang Sering Terabaikan.

https://www.kompasiana.com/natashya3016/58863eb1369773311055009a/i ndustri-film-indonesia-potensi-berharga-yang-sering-terabaikan?page=all . Accessed on October 22, 2019.

Jerussalem, Mohammad Adam. (2009). Perancangan Industri Kreatif Bidang Fashion dengan Pendekatan Benchmarking pada Queensland's Creative Industry. Prosiding Seminar Nasional Program Studi Teknik Busana. Yogyakarta: Universitas Negeri Yogyakarta.

Kominfo. (2015). Jadikan Indonesia Mandiri, Berkepribadian, dan Berdaulat. https://kominfo.go.id/index.php/content/detail/5629/NAWACITA\%3A+9+P rogram+Perubahan+Untuk+Indonesia/0/infografis. Accessed on October 19, 2019.

Kompas.com. (2019). Tumbuh Pesat, Jokowi Optimis Industri Kreatif Jadi Kekuatan Indonesia. https://money.kompas.com/read/2019/03/21/082000826/tumbuh-pesatjokowi-optimis-industri-kreatif-jadi-kekuatan-indonesia?page=all. Accessed on October 19, 2019.

Lazzeretti, L., Boix, R., \& Capone, F. (2013). Why do creative industries cluster? In L. Lazzeretti (Ed.), Creative industries and innovation in Europe (pp. 4564).

LPPM UK Petra. (2015). Peran Strategis Seni Budaya dalam Membangun Kota Kreatif. http://lppm.petra.ac.id/index.php/en/penelitian/ pedomanpelaksanaan.html. Accessed on October 24, 2019.

Primorac, Jaka. (2006). The position of cultural workers in creative industries: the south-eastern European perspective. European Cultural Foundation.

Purnomo, R. A. (2016). Ekonomi Kreatif Pilar Pembangunan Indonesia. Ziyad Visi Media.

Susanto, Heri. (2019). Tumbuh Pesat, Indonesia Pasar Potensial bagi Industri Film. https://katadata.co.id/berita/2019/03/16/tumbuh-pesat-indonesia-pasarpotensial-bagi-industri-film. Accessed on October 19, 2019.

Sutrisno, Hadi. (2004). Analisis Regresi. Yogyakarta: Andi Offset. 
Sulistyoningrum, Yulianisa. (2015). Industri Film: Peran Pemerintah Daerah Masih Minim. https://lifestyle.bisnis.com/read/20151203/254/498283/industrifilm-peran-pemerintah-daerah-masih-minim. Accessed on October 22, 2019 UNCTAD. (2008). Creative economy report 2008. United Nations. 